\title{
Az egészségfejlesztés helyzete az ELTE Pedagógiai és Pszichológiai Karon
}

\author{
Kraiciné Szokoly Mária*
}

Az ELTE Szenátusa 2018 őszén elfogadta az egyetem Egészségfejlesztési stratégiáját, amely hangsúlyozza a diplomások népegészségüggyel kapcsolatos társadalmi jelentőségét és az egyetem szerepét a hallgatók egészségfejlesztési szemléletének, egészségtudatos életmódjának megalapozásában. A stratégia megalapozása céljából a 2015/16-os és a 2016/17-es tanévben kérdőives vizsgálat készült az ELTE Pedagógiai és Pszichológiai Karán az egészségfejlesztés helyzetéröl. A kérdöíves vizsgálat eredménye szerint a megkérdezett oktatók fele, a hallgatók valamivel kevesebb, mint fele fontosnak, de nem elsődlegesnek tartja az egészségfejlesztést az egyetemen. Kiemelik a táplálkozás és a mozgás jelentőségét, de ennek megvalósulásához kedvezőtlennek tartják az egyetemi környezetet. Akadályozó tényező az étkezési körülmények kedvezötlen volta, s az, hogy a kar földrajzi széttagoltság miatt az órarendek nem teszik lehetóvé a hallgatók és oktatók rendszeres étkezését. Mind a fóvárosi, mind a szombathelyi oktatói és hallgatói vizsgálat eredménye szerint kedvezőtlenek az egészség általános mutatói, magas a dohányzás és alkoholfogyasztás mutatója. Az alvásidő minden csoportban átlagosnak tekinthető, az internetezésre fordított idő minden csoportban magas. A megkérdezettek bizonytalanok egészségtudatos magatartásuk hatását illetően, kevéssé látják át hivatásuk egészségfejlesztési vonatkozásait.

Kulcsszavak: egészségfejlesztés, hallgatói-oktatói életmód, egészségfejlesztő egyetemi környezet

\section{Bevezetés}

Európai uniós dokumentumok sora hívja fel a figyelmet arra, hogy az iskolázottság és a felnőttkori tanulás, döntő meghatározója egyrészt a globális világ, benne Európa fejlődésének, versenyképességének, másrészt az egyes polgárok életminőségének, boldogulásának. A WHO „Egészséget mindenkinek” globális programjának alapelve kimondja, hogy az egészség nem kizárólag a szakértők munkáján múlik, mindinkább a közösségi kezdeményezéseken, a célként kitűzött társadalmi igazságon és a szektorok között megvalósuló együttműködésen.

Az emberek értékpreferenciáira irányuló vizsgálatok szerint az emberek számára az egészség, mint érték az első három helyen szerepet kap (Czippán et al., 2015). Ugyanakkor a mai magyar társadalom egészségi állapota kritikus, annak ellenére, hogy a lakosság egészségmagatartása jelentős mértékben befolyásolható, változtatható. A felsőoktatási intézmények egészségfejlesztéssel kapcsolatos aktivitása a népegészségügy komoly tényezőjévé válhatna, nagyban hozzájárulva a társadalom egészségnyereségének növeléséhez, míg az egyetemek passzivitása közrejátszhat a társadalom betegségterheinek növekedéséhez és az életminőség romlásához (Czippán et al., 2015).

Az egészség-fogalom ' jelentős változásokon ment át az elmúlt évtizedek során (Benkő, 1997, Székely et al., 2007; Borbás et al., 2008). Kutatásunkban az Egészségügyi Világszervezet fogalmából indultunk ki, amely szerint „Az egészség az ember teljes testi, lelki és szociális jólétét jelenti, és nem csupán a betegség vagy fogyaté -

címzetes egyetemi docens, ELTE PPK Felnőttképzés-kutatási és Tudásmenedzsment Intézet, e-mail: szokoly.maria@ppk.elte.hu

1. Az egészség és egészségfejlesztés fogalmának értelmezését részletesen kifejtettük a témához kapcsolódó korábbi tanulmá nyunkban: Bárdos Gy. \& Kraiciné Szokoly M. (2018). Egészség, életmód, egészségfejlesztés a felsőoktatás szemszögéből. Neveléstudomány 2018, 2. 5-21. DOI: 10.21549/NTNY.22.2018.2.1 
kosság hiányát" (WHO, 1948). E definíciót az un. Ottawai Karta 1986-ban kiegészítette azzal, hogy az egészség pozitív fogalom (nem csak a betegség hiánya), társadalmi és egyéni erőforrás, és alapfeltételei: béke, lakás, oktatás, élelem, jövedelem, stabil ökológiai rendszer, fenntartható erőforrások, társadalmi igazságosság, egyenlőség (Ottawai Karta, 1986). Az egészség zavarait és az ehhez tartozó háttérmechanizmusokat G.T. Engel (Engel, 1977) ún. bio-pszicho-szociális modelljére alapoztunk, amely az egészséget a szélesen értelmezett kultúra részeként tételezi és az egészség megőrzését társadalmi feladatnak tekinti, amelyhez megfelelő intézményrendszer, pénz, közakarat, de sok tekintetben az egyén felelőssége is szükséges, amit jelentős mértékben meghatároz az egyén életmódja.

Az egészségfejlesztés viszonylag új fogalomnak számít, s az elmúlt évek során az angol nyelvú szakirodalomban számos fogalom és definíció jelent meg: health protection (egészségvédelem), health promotion (egészségfejlesztés), health education (egészségnevelés). ${ }^{2}$ Dolgozatunkban a WHO által javasolt alábbi egészségfejlesztés fogalmat használtuk „Az egészségfejlesztés az a folyamat mely képessé teszi az embereket arra, hogy saját egészségüket felügyeljék és javítsák. Az egészségfejlesztés átfogó társadalmi és politikai folyamat, mely nemcsak az egyének képességeinek és jártasságának erősítésére irányuló cselekvéseket foglal magába, hanem olyan tevékenységeket is, amelyek a társadalmi, környezeti és gazdasági feltételek megváltoztatására irányulnak azért, hogy azoknak a köz és az egyén egészségére gyakorolt hatása kedvező legyen." Ennek alapján tehát az egészségfejlesztés a lakosság egészséggel kapcsolatos múveltségének (egészségkultúrájának) széles körű fejlesztésére, az egészségtudatos magatartásra, az egészséget veszélyeztető ártalmak, a megbetegedések megelőzésére irányuló tevékenység (Kishegyi \& Makara, 2004; Gritz, 2007; Benkő, 2009). Tudományos értelemben az egészségnevelés biopszicho-szociális megközelítésű „határtudomány”: az orvostudományokon kívül épít a pszichológia, a neveléstudomány, a szociológia tudományos eredményeire, módszereire (Bárdos \& Kraiciné, 2018).

A tanulmányunkban részletezett vizsgálattal és az egyetemi egészségfejlesztési stratégia kidolgozásával nemcsak az egyetemi polgárok (hallgatók, oktatók, dolgozók, kutatók) egészségének és életminőségének előmozdítását céloztuk, hanem azt is reméltük, hogy a magyar egyetemek belépnek a nemzetközi „brandet” jelentő Egészségfejlesztő Egyetemek táborába (Health Promoting Universities). Ezt indokolja az a tény, hogy Magyarországon a kilencvenes évekhez képest megháromszorozódott a felsőoktatásban résztvevők aránya, s e népes populációban tudatosan kellene építeni az egyetemek kettős népegészségügyi hatására. Egyrészről a hallgatók az egyetemi éveik alatt megszerzett egészségfejlesztési szemlélet és ismeretek, valamint az egészséges életmódot kialakító egyetemi lehetőségek igénybevételének köszönhetően kiépít(he)tik további életük minőségét meghatározó egészségtudatos magatartásukat, életvitelüket; másrészt az egyetemről kikerülve egészségtudatos értelmiségi szakemberként mintaértékű magatartásukkal és szakmai döntéseikkel alapvetően befolyásolhatják a népesség egészségmagatartását (Kraiciné Szokoly, 2016).

Ami az egészségfejlesztés lehetséges színtereit illeti, az egészségfejlesztés átfogja az emberek egész életútját és annak minden színterét. Az egyetem sokszínú egészségfejlesztési színtér, mert a hallgatók számára az életük legfogékonyabb szakaszában életmódot meghatározó tanulási színtér, míg a dolgozók számára munkahelyi környezet. Ugyanakkor az egyetem, mint tudományos-kulturális szellemi központ, harmadik missziójából adódóan meghatározó jelentőségű a szűkebb és tágabb környezetben élők életminősége szempontjából is.

Az alábbi ábra mutatja, hogy egészséget meghatározó tényezők széleskörǔek egymással kölcsönösen öszszefüggenek, amint azt az Ottawai Charta is megállapította: „Az egészséget az emberek a mindennapi életük

2. Magyarországon „Az egészségügyről szóló 1997. évi CLIV. törvény (Hatályos: 2015. 01. 30 - 2015. 06. 30) 37. § (1) - (2) bekezdé$s e$ " határozza meg az egészségfejlesztést. 
körülményei között teremtik és élik meg; ott, ahol tanulnak, dolgoznak, játszanak és szeretnek. Az egészséget a magunkról és másokról való gondoskodás közben teremtjük azáltal, hogy képesek vagyunk döntéseket hozni és ellenőrzésünk alatt tartani életkörülményeinket, továbbá azáltal, hogy a társadalom és a közösség, amelyben élünk olyan feltételeket teremt, amelyek lehetővé teszik a lehető legjobb egészségi állapot elérését a közösség összes tagja számára." ${ }^{3}$

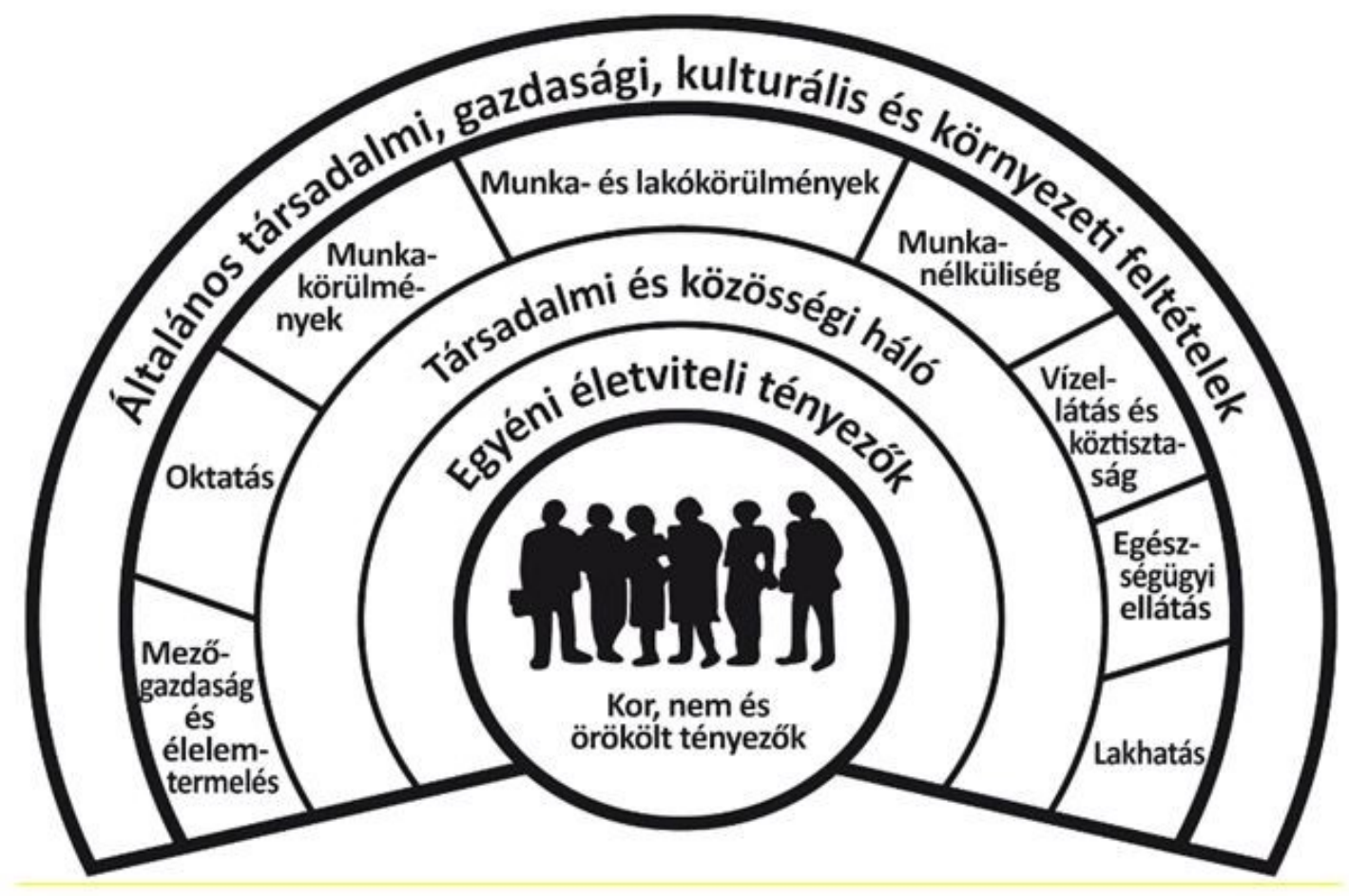

1. ábra: Az egészséget meghatározó tényezők

Forrás: Koós 2014. Eredeti forrás: Dahlgren, G. -Whitehead, M. (1991) Policies and strategies to promote social equity in health. Stockholm, Institute for Future Studies.)

A közösségekre irányuló - WHO meghatározása szerinti - egészségfejlesztés egy egyetem esetében az in tézmény valamennyi területét érinti és múködésének rendszerszintú átgondolását igényli. Az egyetemi egészségfejlesztő program kulcseleme a hallgatók és oktatók egészséges életmódja, a megfelelő táplálkozás, a rendszeres testmozgás, a szabadidő hasznos eltöltése, de ide értendő a hallgatóközpontú oktatás és a hallgatóbarát oktatásszervezés, a hallgatók bevonása a kutatásba, továbbá ide értendő az egyetem harmadik missziója is: az egészségfejlesztési célzatú együttmúködés a település, régió helyi szervezeteivel.

Minden ember egészsége, életminősége a születéstől kezdve késő kamaszkorig emelkedő tendenciát mutat, és az ezt követő életszakaszokban eléri maximumát, majd hanyatlásnak indul. Az egészségfejlesztési célok lényege éppen ezért az, hogy az emberek életminősége eleve minél jobb helyzetből induljon, és a hanyatlás minél később következzen be. A görbe ilyen irányú változtatása az, ami az ún. „egészségnyereséget” eredményezheti (Czippán et al., 2015).

3. Ottawa Charter for Health Promotion, 1986. Retrieved from http://www.euro.who.int/__data/assets/pdf_file/0004/129532/ Ottawa_Charter.pdf (2017. 07. 30) 
Az egyetemista élet bizonyos tekintetben „védett” létforma, mert a hallgató jogi értelemben már felnőtt, éppen a felnőtté válás göröngyös útját próbálgatja, azonban életvezetését még számos tényező védi. Az egyetemi környezetben eltöltött évek, a hallgatói életmód tapasztalatai alapvetően meghatározzák a későbbi, a fel nőttkori életmódot és életminőséget és megalapozói annak a magatartásnak, amely az értelmiség társadalmi modellszerepéből következően - függetlenül a diploma szakterületétől - széles körben képes terjeszteni az egészséget kiemelt értékként kezelő szemléletet, megalapozhatja a lakosság körében az egészségfejlesztés gyakorlatát.

Az egészséget szolgáló közpolitika és ellátási rendszer mellett nagy jelentősége van az egészségtudatos életmódra nevelésnek, ezen belül az oktatási rendszernek az óvodától az egyetemig bezárólag, azonban a közoktatási és a felsőoktatási szintek szerepe az egészség-nevelésben alapvetően eltérő. A három szint (St Leger, 2001) a következő:

a) meghatározott tudásanyag átadása (pl. önértékelés, testkép)

b) meghatározott kompetenciák fejlesztése (pl. a jellemző egészségügyi problémák megismerése),

c) meghatározott társadalmi készségek fejlesztése (pl. saját egészségi állapottal való törődés).

A közoktatás feladata a túléléshez szükséges első két szint tudás- és képesség anyagának az elsajátíttatása, amelyek nagymértékben befolyásolják az egyéni életminőséget és életkilátásokat. A harmadik szint elsajátíttatása már inkább a közép- és felsőoktatás feladata lehet, így az egyetemi programok megszervezésénél is elsősorban a társadalmi képességek fejlesztésére érdemes koncentrálni. Az államilag kötelező iskoláztatás időszakában a mozgást és a megfelelő táplálkozást főként külső szocializációs tényezők befolyásolják (család, iskola, az állam törvényei). Ez a fajta gondoskodás a felsőoktatás időszakára gyakorlatilag megszűnik. A fiatal felnőtteket, így az egyetemi hallgatókat nem „kényszerítik” mindennapi testmozgásra vagy megfelelő időpontban történő étkezésre. Tehát elmondhatjuk, hogy születéstől a fiatalkor eléréséig az egészség birtoklása egyrészt a biológiai kor általános jellemzője, másrészt a társadalmi gondoskodás miatt egyfajta életkori sajátosság, szinte természetes állapot (Bíróné, 2011).

\section{Az egészségfejlesztés helyzete az ELTE Pedagógiai és Pszichológiai Karon}

\section{A vizsgálat elözményei}

2015/16. tanévben egy oktatói munkacsoport felmérést végzett az ELTE PPK-n azzal a céllal, hogy információt szerezzen a hallgatók és oktatók egészségmagatartásáról, egészségfejlesztésről alkotott vélekedéseiről.

A 2017/18-as tanévtől - a felsőoktatás rendszerének átalakítása következtében - a Nyugat-magyarországi Egyetem több szervezeti egysége az ELTE keretében folytatja munkáját. ${ }^{4}$ Ez a szerkezeti átalakulás volt az apropója annak, hogy az ELTE PPK egészségfejlesztési helyzetére vonatkozó 2015-ben elvégzett kérdőíves vizsgálatot - a kérdések érdemi megváltoztatása nélkül - 2016 novemberében megismételjük a Nyugat-magyarországi Egyetem Berzsenyi Dániel Pedagógusképző Karon, az immár ELTE PPK-ba beolvadt szombathelyi szervezeti egységek ${ }^{5}$ (továbbiakban SEK) hallgatói és oktatói körében, majd összevessük a két vizsgálat eredményeit.

4. A Savaria Egyetemi Központ Neveléstudományi és Sporttudományi Intézete az ELTE PPK keretében folytatja tevékenységét, ELTE Savaria Egyetemi Központ néven. Retrieved from https://www.elte.hu/savaria (2017. 04. 09.)

5. Retrieved from http://integracio.elte.hu/wordpress/index.php/hova-tartozom/ (2017. 04. 10.) 
A vizsgálatok pilot kutatás jelleggel az ELTE 2018-ban elfogadott Egészségfejlesztési stratégiájának ${ }^{6}$ elózményét és megalapozását is jelentették. Annak ellenére, hogy a felmérés az egész egyetemre nézve nem volt reprezentatív, a válaszok egyértelmúek, és számos tanulsággal szolgáltak a stratégia elkészítéséhez.

A vizsgálat kezdeményezői feltételezték, hogy annak ellenére, hogy az ELTE PPK szakjainak többsége érinti az egészségfejlesztés kérdéskörét, nem következik az, hogy operatív értelemben a kar, - áttételesen maga az egyetem - egészségfejlesztő egyetemként működne. Az egészségfejlesztő egyetem létrehozásához ugyanis számos rendszerszemléletű, az egyetem szinte összes müködési folyamatára kiterjedő rendszerfejlesztésre, szervezetfejlesztésre, szolgáltatásfejlesztésre volna szükség, amelyet egyetemi szinten stratégiai kérdésként kell kezelni. Az egyetemi egészségfejlesztés stratégiai megközelítésének fontosságára hívta fel a figyelmet a TÁMOP 6.1.1.-12/12013-0001 „Egészségfejlesztési szakmai hálózat létrehozása” kiemelt projekt felsőoktatási alprojektje. Eszerint a szakok célját és tartalmát meghatározó képzési és kimeneti követelmények többségében az egészségvédelem/egészségfejlesztés szempontjai egyáltalán nem szerepelnek, még az olyan, a PPK-n működő szakok esetében sem, mint például a pszichológia, a pedagógia, vagy a sporttudományi szakok. A TÁMOP kutatás fontos megállapítása, hogy ha egy intézmény nem rendelkezik kifejezett egészségfejlesztési koncepcióval és stratégiával, akkor ez a szempont az adott intézményben szinte egyáltalán nem érvényesül.

\section{Kutatási kérdések, hipotézisek}

Vizsgálatunkban arra kerestük a választ, hogy a megkérdezett hallgatók és oktatók milyen jelentőséget tulajdonítanak az egyetemi egészségfejlesztésnek, körükben megjelenik-e, ha igen, milyen módon az egészségfejlesztés iránti igény. Milyennek látják saját intézményi környezetüket az egészségfejlesztés szempontból, illetve mely egészségmagatartási formákat vallják magukénak. Kíváncsiak voltunk, hogy van-e különbség az ELTE PPK és az ELTE Savaria Egyetemi Központ oktatóinak, kutatóinak, dolgozóinak és hallgatóinak egészségről való vélekedése, gondolkodása között.

Hipotézisünk szerint a kutatásba bevont hallgatók és oktatók többségét - szaktól és tagozattól függetlenül - érdekli az egészségfejlesztés témaköre, illetve a megkérdezettek saját egészségének szubjektív megítélése összefügg egészségmagatartásukkal. Feltételeztük, hogy a megkérdezettek hallgatói és oktatói létükből adódóan számos stresszor tényezőnek vannak kitéve, továbbá azt, hogy a stressz és a rizikó-magatartás összefügg.

\section{A minta}

Az ELTE PPK-n a 2015/2016-os tanév tavaszi félévében végzett online oktatói és hallgatói kérdőíves lekérde zés során 90 oktatótól és 182 hallgatótól érkezett vissza értékelhető válasz. A hallgatói és oktatói kérdőivek összeállítása az egészségfejlesztési koncepció kidolgozásával megbízott munkacsoport közös munkája volt, amelyek kidolgozásakor korábbi kutatásokban felhasznált kérdőíveket, validált mérőeszközöket is felhasználtak. $^{7}$

A 2016/17. tanév őszi félévében megismételt oktatói és hallgatói online kérdőíveket a Nyugat-Magyarországi Egyetem Berzsenyi Dániel Pedagógusképző Kar Sporttudományi Intézete juttatta el 1875 hallgatóhoz és

6. Az ELTE Egészségfejlesztési stratégiája Retrieved from https://www.elte.hu/dstore/document/1935/ELTE_Eg\%C3\%A9szs \%C3\%A9gfejleszt\%C3\%A9si_strat\%C3\%A9gia.pdf (2019.03. 15.)

7. A munkacsoport tagjai voltak: Dr. Bárdos György egy. tanár (PPK ESI), Dr. Berkes Tímea adjunktus (PPK ESI), Dr. Boros Szilvia adjunktus (PPK ESI), Koppány Katalin (külső szakértő, NEFI) Kraiciné Dr. Szokoly Mária docens, (PPK NTI), Mészárosné Dr. Darvay Sarolta docens (TÓK TTT), Patakiné Dr. Bősze Júlia adjunktus (PPK ESI), Dr. Szanitrik Zsuzsa foglalkozás egészségügyi orvos (ELTE), Dr. Vitályos Gábor Áron adjunktus (TÓK TTT). A SEK-en folyó vizsgálatban részt vett Kraiciné Szokoly Mária 
181 oktatóhoz. A visszaérkezett és értékelhető hallgatói kérdőívek száma 182, az oktatói kérdőívek száma 24. A 2017. évi online kérdőív a 2016. évi online kérdőív mintájára készült, összesen 53 kérdést tartalmazott (4 nyitott és 49 zárt kérdés, utóbbiak között alternatív, szelektív és skála-szintű kérdésekkel.) A kérdőíves vizsgálat és az összegyűjtött adatok feldolgozása Microsoft Office Excel 2016 táblázatkezelő program, a diagramok készítése pedig a Microsoft Office Word 2016 szövegszerkesztő program segítségével történt.

A nemi arányokat tekintve a hallgatók esetében a SEK-en több a férfi válaszoló hallgató, mint a PPK-n (71-31 fö), az oktatók esetében az ELTE PPK-n jelentős túlsúlyban vannak a női válaszadók (71-14fö).

\begin{tabular}{|lrr|rr|}
\hline & PPK oktatók & PPK hallgatók & \multicolumn{1}{c|}{ SEK oktatók } & \multicolumn{1}{c|}{ SEK hallgatók } \\
\hline Férfi & $19(21 \%)$ & $31(17 \%)$ & $10(41,7 \%)$ & $71(39 \%)$ \\
\hline Nő & $71(79 \%)$ & $151(83 \%)$ & $14(58,3 \%)$ & $111(61 \%)$ \\
\hline N & 90 & 182 & 24 & 182 \\
\hline
\end{tabular}

A PPK és a SEK mintában a résztvevők életkora közel azonos, nagyjából megegyező az átlagéletkor is, és nagyjából azonos a nappali tagozatos hallgatók aránya, a SEK-en azonban 14\%-kal több a levelező tagozatos válaszoló.

\begin{tabular}{|c|c|c|c|c|}
\hline & $\begin{array}{c}\text { PPK } \\
\text { oktatók }\end{array}$ & $\begin{array}{c}\text { PPK } \\
\text { hallgatók }\end{array}$ & $\begin{array}{c}\text { SEK } \\
\text { oktatók }\end{array}$ & $\begin{array}{c}\text { SEK } \\
\text { hallgatók }\end{array}$ \\
\hline Átlagéletkor (év) & 44 & 27 & 50 & 26 \\
\hline Munkakör - oktató, kutató & $51 \%$ & & $83 \%$ & \\
\hline Jogviszony - nappali & & $75 \%$ & & $78 \%$ \\
\hline Jogviszony - levelező & & $8 \%$ & & $22 \%$ \\
\hline Jogviszony - esti tagozat & & $17 \%$ & & - \\
\hline $\begin{array}{l}\text { Sporttal, egészségfejlesztéssel } \\
\text { kapcsolatos szakon tanít/tanul }\end{array}$ & $?$ & $?$ & $42 \%$ & $40 \%$ \\
\hline $\mathbf{N}$ & 90 & 182 & 24 & 182 \\
\hline
\end{tabular}

2. táblázat: A résztvevők átlagéletkora, információk az intézményben elfoglalt szerepről 


\begin{tabular}{|c|c|c|c|c|}
\hline $\begin{array}{c}\text { Összességében, hogy érzi, } \\
\text { anyagilag... }\end{array}$ & $\begin{array}{c}\text { PPK } \\
\text { oktatók }\end{array}$ & $\begin{array}{c}\text { PPK } \\
\text { hallgatók }\end{array}$ & $\begin{array}{c}\text { SEK } \\
\text { oktatók }\end{array}$ & $\begin{array}{c}\text { SEK } \\
\text { hallgatók }\end{array}$ \\
\hline Gondok nélkül él & $63 \%$ & $68 \%$ & $33 \%$ & $15.4 \%$ \\
\hline $\begin{array}{l}\text { Éppen, hogy kijön a } \\
\text { jövedelméből }\end{array}$ & $27 \%$ & $28 \%$ & $8 \%$ & $22,5 \%$ \\
\hline $\begin{array}{l}\text { Hónapról-hónapra } \\
\text { anyagi gondjai vannak }\end{array}$ & $10 \%$ & $4 \%$ & $4 \%$ & $6 \%$ \\
\hline Nélkülözések között él & - & - & - & $2,7 \%$ \\
\hline $\mathbf{N}$ & 90 & 182 & 24 & 182 \\
\hline
\end{tabular}

A kérdőív rákérdezett a válaszolók anyagi helyzetére, mivel ez az életmód-életvitel, az egészségfejlesztés szempontjából nem elhanyagolható. A fenti táblázat mutatja, hogy az ELTE PPK oktatóinak és hallgatóinak anyagi helyzete jobb, mint a SEK megkérdezettjeinek.

Az egészség általános mutatói

\begin{tabular}{lrrr|r} 
& $\begin{array}{c}\text { PPK } \\
\text { oktatók }\end{array}$ & $\begin{array}{c}\text { PPK } \\
\text { hallgatók }\end{array}$ & $\begin{array}{c}\text { SEK } \\
\text { oktatók }\end{array}$ & \multicolumn{1}{c|}{$\begin{array}{c}\text { SEK } \\
\text { hallgatók }\end{array}$} \\
\hline Napi átlagos alvásidő (óra) & 6,7 & 7,16 & 7,7 & 6,9 \\
Napi internet óraszáma & 5,5 & 4,6 & 3,5 & 4,9 \\
BMI & 24,45 & 22,76 & 25,6 & $\mathbf{2 3 , 5}$ \\
BMI érték & $\begin{array}{c}\text { normál, de } \\
\text { majdnem } \\
\text { túlsúlyos } \\
\text { kategória }\end{array}$ & normál & túlsúlyos & normál \\
& & &
\end{tabular}

4. táblázat: A résztvevők napi alvásideje, internethasználata és testtömeg indexe (BMI)

Az egészség általános mutatói közül fontosságánál fogva kiemelendő a testtömeg index. A két oktatói mintába tartozók egyaránt a normál, illetve majdnem túlsúlyos kategóriába tartoznak, míg hallgatók esetében mindkét minta válaszadói a normál kategóriába tartoznak. Az alvásidő minden csoportban átlagosnak tekinthető, míg az internetezésre fordított idő minden csoportban magas, különösen a PPK oktatói esetében.

\section{Étkezés}

Ami az étkezést illeti az oktatók esetében nagy az eltérés az egészségesnek, általánosnak mondható napi háromszori étkezéstől és érdekes, hogy több mint $10 \%$ a speciális étrendet követők aránya. Ez is indokolhatja azt a tényt, ami a 6. táblázatból olvasható ki, hogy igen magas a PPK-n a megfeleló étrendet nem találó oktatók aránya (53\%), hallgatók aránya (59\%!) 


\begin{tabular}{lrrr|r|}
\multicolumn{1}{c}{ Étkezés I. } & $\begin{array}{c}\text { PPK } \\
\text { oktatók }\end{array}$ & $\begin{array}{c}\text { PPK } \\
\text { hallgatók }\end{array}$ & $\begin{array}{c}\text { SEK } \\
\text { oktatók }\end{array}$ & \multicolumn{1}{c|}{$\begin{array}{c}\text { SEK } \\
\text { hallgatók }\end{array}$} \\
\hline Napi háromszor & $51 \%$ & $37 \%$ & $83 \%$ & $35 \%$ \\
Napi ötször & $20 \%$ & $25 \%$ & $4,2 \%$ & $26 \%$ \\
Rendszertelenül & $12 \%$ & $28 \%$ & $4 \%$ & $30 \%$ \\
Speciális étrend & $10 \%$ & $14 \%$ & $16,7 \%$ & $6 \%$ \\
N & 90 & 182 & 24 & 182 \\
& & 5. táblázat: Hogyan étkezik egy átlagos napon?
\end{tabular}

\begin{tabular}{lrrr|r|}
\multicolumn{1}{c}{ Étkezés II. Akadályok } & \multicolumn{1}{c}{$\begin{array}{c}\text { PPK } \\
\text { oktatók }\end{array}$} & $\begin{array}{c}\text { PPK } \\
\text { hallgatók }\end{array}$ & $\begin{array}{c}\text { SEK } \\
\text { oktatók }\end{array}$ & \multicolumn{1}{c|}{$\begin{array}{c}\text { SEK } \\
\text { hallgatók }\end{array}$} \\
\hline Nincs elég ido” & $39 \%$ & $49 \%$ & $33,3 \%$ & $57 \%$ \\
\hline $\begin{array}{l}\text { Nem talál étrendjének } \\
\text { megfeleló ételeket }\end{array}$ & $53 \%$ & $59 \%$ & $20,8 \%$ & $18,1 \%$ \\
\hline Drága & $44 \%$ & $55 \%$ & $20,8 \%$ & $16,5 \%$ \\
\hline N & 90 & 182 & 24 & 182 \\
\hline & & 6. táblázat: Miért nem étkezik rendszeresen?
\end{tabular}


Dohányzás, alkohol, drog

PPK oktatók PPK hallgatók SEK oktatók SEK hallgatók

\section{Dohányzás}

\begin{tabular}{lrrrr}
\hline Nem, soha & $57 \%$ & $62 \%$ & $62,50 \%$ & $73,10 \%$ \\
Naponta & $11 \%$ & $5 \%$ & $12,50 \%$ & $7,70 \%$ \\
Alkalmanként & $13 \%$ & $22 \%$ & - & $8,80 \%$ \\
Leszokott & $18 \%$ & $10 \%$ & $25 \%$ & $3,80 \%$ \\
N & 90 & 182 & 24 & 182 \\
\hline
\end{tabular}

Alkohol az elmúlt 12 hónapban

\begin{tabular}{|c|c|c|c|c|}
\hline $\begin{array}{l}\text { Havonta, vagy annál } \\
\text { ritkábban }\end{array}$ & $57 \%$ & $56 \%$ & $62,50 \%$ & $73,10 \%$ \\
\hline Havi 2-4 alkalommal & $16 \%$ & $32 \%$ & $12,50 \%$ & $7,70 \%$ \\
\hline Heti 2-3 alkalommal & $21 \%$ & $8 \%$ & - & $8,80 \%$ \\
\hline $\begin{array}{l}\text { Hetente 4-szer } \\
\text { vagy többször }\end{array}$ & $6 \%$ & $11 \%$ & $25 \%$ & $3,80 \%$ \\
\hline Leggyakoribb & bor (75\%) & bor (50\%) & bor $(78,3 \%)$ & $\begin{array}{r}\text { bor }(47,8 \%), \\
\text { sör }(42,1 \%), \text { tömény } \\
(38,8 \%)\end{array}$ \\
\hline $\mathbf{N}$ & 90 & 182 & 24 & 182 \\
\hline \multicolumn{5}{|c|}{ Illegális pszichoaktív vagy új pszichoaktív anyag } \\
\hline Nem, soha & $77 \%$ & $70 \%$ & $100 \%$ & $91,8 \%$ \\
\hline 14-18 év között & - & $14 \%$ & & $33,3 \%$ \\
\hline 18-24 év között & - & $27 \%$ & & $38,9 \%$ \\
\hline 1 évnél régebben & $41 \%$ & $21 \%$ & & $5,6 \%$ \\
\hline Az elmúlt 1 évben & $18 \%$ & $21 \%$ & & $5,6 \%$ \\
\hline 1 hónapon belül & $9 \%$ & $17 \%$ & & $11,1 \%$ \\
\hline Leggyakoribb & marihuána (82\%) & $\begin{array}{l}\text { marihuána } \\
\text { (93\%) }\end{array}$ & & $\begin{array}{r}\text { marihuána (100\%), } \\
\text { varázsgomba }(21,4 \%)\end{array}$ \\
\hline $\mathbf{N}$ & 90 & 182 & 24 & 182 \\
\hline
\end{tabular}

7. táblázat: Dohányzás, alkoholfogyasztás és droghasználat.

A rendszeres dohányzás vonatkozásában, nincs lényeges különbség a PPK és a SEK adatok között, viszont a SEKen valamivel többen dohányoznak, ami meglepő ahhoz képest, hogy az oktatók jelentős része foglalkozik sporttal, egészségfejlesztéssel. A PPK megkérdezett hallgatói több alkoholt fogyasztanak, mint a SEK hallgatók. Aggasztó, hogy a SEK hallgatók közül 69 válaszadó (38,8\%) a tömény italokat részesíti elónyben. A drogfogyasztás vonatkozásában nincs lényeges különbség. Meglátásunk szerint a válaszokat összegző adatok nem feltétlenül informatívak, vélhetően sok az elvárt válasz. 
Életmód: összefüggések a hétköznapi jólléttel

A szubjektív jóllétnek számos olyan komponense, meghatározója van, amelyek a vizsgált célcsoport életvitelében meghatározó jelentőségűek és számos kutatás érintette az elmúlt időszakban (Petőné Csima, 2012; Harsányiné Petneházi, 2013; Makra \& Balogh, 2018). Az életmódot illetően a kérdőív kitér a hétköznapi jóllét néhány vonatkozására, feltételének meglétére, közöttük a szubjektív jóllétre és a szabadidővel való kapcsolatára.

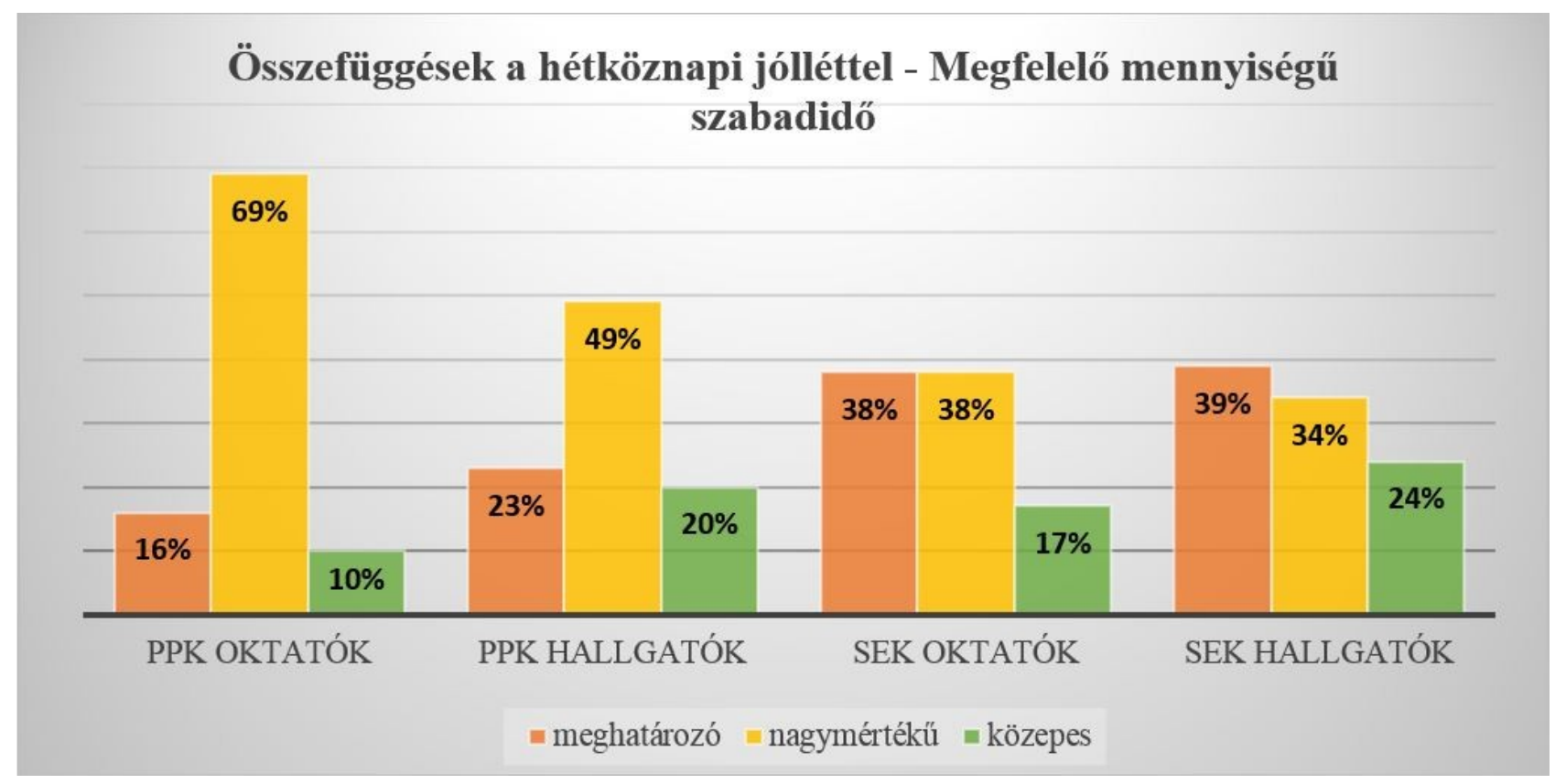

2. ábra: A megfelelő mennyiségú szabadidő összefüggése a hétköznapi jólléttel.

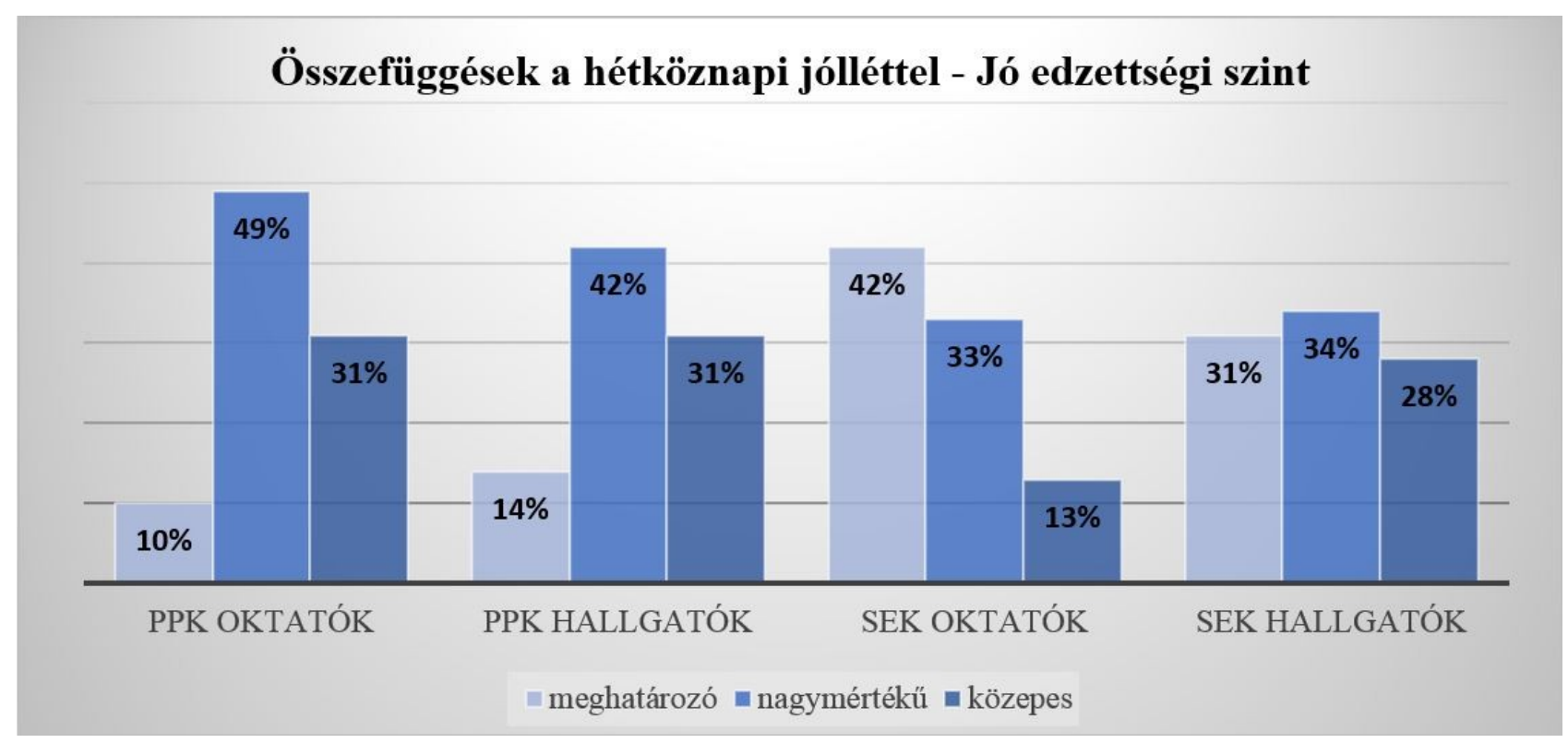

3. ábra: Az edzettségi szint összefüggése a hétköznapi jólléttel 


\section{Összefüggések a hétköznapi jólléttel - Kiegyensúlyozott társas kapcsolatok}

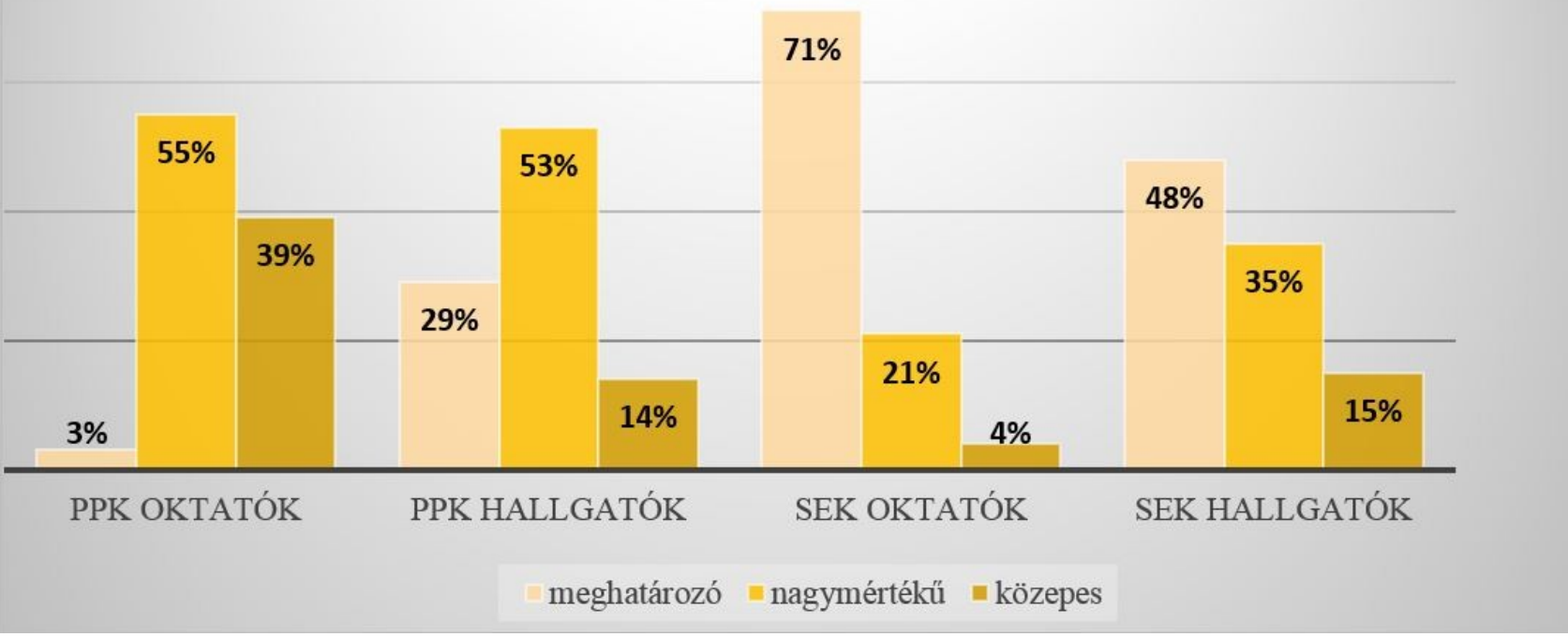

4. ábra: A kiegyensúlyozott társas kapcsolatok összefüggése a hétköznapi jólléttel

A fiatal felnőttek életét nagymértékben befolyásolja az edzettségi szintjük, ami alatt a fizikai aktivitásra al kalmas szervezeti háttér (izomrendszer, keringési és légzési rendszer) szintjét értjük (Makra \& Balogh, 2018). Edzettnek az tekinthető, aki rendszeres, az átlagot meghaladó fizikai (sport) teljesítményre képes.

A megkérdezettek a jó edzettségi szintet és az elegendő szabadidőt mindkét szervezeti egységben meghatározónak tartják, a szabadidő iránti igény tekintetében sincs jelentős különbség. Mindkét szervezeti egységben korrelációt mutat a kiegyensúlyozott társas kapcsolat és a hétköznapi jóllét, de a társas kapcsolatokat a szombathelyi oktatók magasabbra értékelik.

Az egészségfejlesztés jelentőségéről, a választott hivatás társadalmi hatásáról való vélekedések

Ami az egészségfejlesztés és egészséges életmódra törekvés egyetemeken történő megvalósulását illeti a 8. táblázat adatai alapján megállapítható, hogy mindkét karon mind az oktatók, mind a hallgatók fontosnak, de nem elsődlegesnek tartják az egyetemi egészségfejlesztést. 


\begin{tabular}{|c|c|c|c|c|c|c|c|c|}
\hline $\begin{array}{c}\text { Egészségfejlesztés, } \\
\text { egészséges } \\
\text { életmódra } \\
\text { törekvés I. }\end{array}$ & \multicolumn{2}{|c|}{ PPK oktatók } & \multicolumn{2}{|c|}{ PPK hallgatók } & \multicolumn{2}{|c|}{ SEK oktatók } & \multicolumn{2}{|c|}{ SEK hallgatók } \\
\hline \multirow[t]{2}{*}{$\begin{array}{l}\text { Fontosnak tartja-e } \\
\text { az Egyetemen? }\end{array}$} & $\begin{array}{l}\text { Kiemelten } \\
\text { fontos }\end{array}$ & $\begin{array}{l}\text { Fontos, } \\
\text { de nem } \\
\text { elsődleges }\end{array}$ & $\begin{array}{l}\text { Kiemelten } \\
\text { fontos }\end{array}$ & $\begin{array}{l}\text { Fontos, } \\
\text { de nem } \\
\text { elsődleges }\end{array}$ & $\begin{array}{l}\text { Kiemelten } \\
\text { fontos }\end{array}$ & $\begin{array}{l}\text { Fontos, } \\
\text { de nem } \\
\text { elsődleges }\end{array}$ & $\begin{array}{l}\text { Kiemelten } \\
\text { fontos }\end{array}$ & $\begin{array}{l}\text { Fontos, } \\
\text { de nem } \\
\text { elsődleges }\end{array}$ \\
\hline & $49 \%$ & $33 \%$ & $42 \%$ & $31 \%$ & $58,3 \%$ & $20,8 \%$ & $33 \%$ & $33,5 \%$ \\
\hline \multirow{2}{*}{$\begin{array}{l}\text { Megjelenik-e az } \\
\text { Egyetem életében, } \\
\text { értéknek számít? }\end{array}$} & Igen & Nem & Igen & Nem & Igen & Nem & Igen & $\mathrm{Nem}$ \\
\hline & $41 \%$ & $59 \%$ & $37 \%$ & $63 \%$ & $83,3 \%$ & $16,7 \%$ & $70,3 \%$ & $29,7 \%$ \\
\hline $\begin{array}{l}\text { Amennyiben } \\
\text { megjelenik, akkor } \\
\text { mely területen? }\end{array}$ & \multicolumn{2}{|c|}{$\begin{array}{l}\text { kutatás (83\%), } \\
\text { társadalmi és speciális } \\
\text { szolgáltatások (69\%), } \\
\text { oktatás (67\%) }\end{array}$} & \multicolumn{2}{|c|}{$\begin{array}{l}\text { oktatás (50\%), } \\
\text { kutatás (50\%) }\end{array}$} & \multicolumn{2}{|c|}{$\begin{array}{l}\text { oktatás (80\%) } \\
\text { kutatás (45\%) }\end{array}$} & \multicolumn{2}{|c|}{$\begin{array}{l}\text { oktatás (70\%) } \\
\text { általános müködés } \\
(33 \%)\end{array}$} \\
\hline
\end{tabular}

8. táblázat: Az egészségfejlesztés szerepe, megvalósulása az egyetemen

Vizsgálatunk szempontjából kiemelkedően fontos volt a válaszadás arra a kérdésre, hogy megjelenik-e az egészségfejlesztés az egyetemen, értéknek számít-e az adott intézményükben az egészség? Erre a kérdésre a SEK-en adott válaszok kedvezőbbek: mind az oktatók, mind a hallgatók úgy gondolják, hogy az egyetemen érték az egészség. Érdekes azonban az a következtetés, hogy az ELTE PPK oktatói közül csupán 41\% gondolja, hogy megjelenik az egyetemen az egészségfejlesztés, sőt ezen válaszolók mintegy háromnegyede (69\%) szerint az egészségfejlesztés csak társadalmi és speciális szolgáltatásokban érhető tetten. A megkérdezett csoportok közül csak a SEK hallgatói jelezték, hogy szerintük az egyetem általános múködésben megjelenik az egészségfejlesztés (33\%). 


\section{Egészségfej- lesztés,} egészséges életmódra

\section{\begin{tabular}{l|lll} 
PPK oktatók & PPK hallgatók $\quad$ SEK oktatók $\quad$ SEK hallgatók
\end{tabular}} törekvés II.

\begin{tabular}{|c|c|c|c|c|c|c|c|c|}
\hline \multirow{2}{*}{$\begin{array}{l}\text { Saját életében } \\
\text { tesz-e valamit } \\
\text { tudatosan } \\
\text { egészsége } \\
\text { fejlesztéséért? }\end{array}$} & $\begin{array}{l}\text { Nagyon } \\
\text { sokat tesz }\end{array}$ & $\begin{array}{l}\text { Igyekszik } \\
\text { beilleszteni }\end{array}$ & $\begin{array}{l}\text { Nagyon } \\
\text { sokat tesz }\end{array}$ & $\begin{array}{l}\text { Igyekszik } \\
\text { beilleszteni }\end{array}$ & $\begin{array}{l}\text { Nagyon } \\
\text { sokat tesz }\end{array}$ & $\begin{array}{l}\text { Igyekszik } \\
\text { beilleszteni }\end{array}$ & $\begin{array}{l}\text { Nagyon } \\
\text { sokat tesz }\end{array}$ & $\begin{array}{l}\text { Igyekszik } \\
\text { beilleszten }\end{array}$ \\
\hline & $19 \%$ & $54 \%$ & $27 \%$ & $52 \%$ & $25 \%$ & $62,5 \%$ & $18,7 \%$ & $47,8 \%$ \\
\hline \multirow{2}{*}{$\begin{array}{l}\text { Van-e az } \\
\text { egészségfejlesz- } \\
\text { tésnek felelőse az } \\
\text { egyetemen? }\end{array}$} & Igen & $\mathrm{Nem}$ & Igen & $\mathrm{Nem}$ & Igen & $\mathrm{Nem}$ & Igen & $\mathrm{Nem}$ \\
\hline & $47 \%$ & $53 \%$ & $60 \%$ & $40 \%$ & $50 \%$ & $50 \%$ & $62,6 \%$ & $37,4 \%$ \\
\hline $\begin{array}{l}\text { Tudatosult-e } \\
\text { Önben valaha, } \\
\text { hogy } \\
\text { szakterülete } \\
\text { gyakorlásának, } \\
\text { hivatásának van } \\
\text { népegészségügyi } \\
\text { hatása? }\end{array}$ & $60 \%$ & $40 \%$ & $86 \%$ & $14 \%$ & $58,3 \%$ & $41,7 \%$ & $56,6 \%$ & $43,4 \%$ \\
\hline $\begin{array}{l}\text { Tudatosult-e } \\
\text { Önben valaha, } \\
\text { hogy életmódja, } \\
\text { életvitele } \\
\text { példaként szolgál } \\
\text { mások számár? }\end{array}$ & $76 \%$ & $24 \%$ & $68 \%$ & $32 \%$ & $75 \%$ & $25 \%$ & $58,6 \%$ & $41,2 \%$ \\
\hline $\begin{array}{l}\text { Van-e az } \\
\text { oktatók, } \\
\text { dolgozók között } \\
\text { egészségfejlesz- } \\
\text { tés szempont- } \\
\text { jából mintaadó } \\
\text { személy? }\end{array}$ & $43 \%$ & $57 \%$ & $44,5 \%$ & $55,5 \%$ & $58,3 \%$ & $41,7 \%$ & $52,2 \%$ & $47,8 \%$ \\
\hline $\begin{array}{l}\text { Kapott-e } \\
\text { egyetemi élete } \\
\text { során tájékozta- } \\
\text { tást/kiképzést } \\
\text { baleset- és } \\
\text { egészségvédelem } \\
\text { tárgykörében? }\end{array}$ & $54 \%$ & $46 \%$ & $35 \%$ & $65 \%$ & $83,3 \%$ & $16,7 \%$ & $78,6 \%$ & $21,4 \%$ \\
\hline
\end{tabular}

9. táblázat: Az egészségfejlesztés, egészséges életmódra törekvés szerepe, megvalósulása az egyetemen 
Hasonlóképpen nagy érdeklődéssel vártuk a választ arra a kérdésre, hogy „Tudatosult-e Önben valaha, hogy szakterülete gyakorlásának, hivatásának van népegészségügyi hatása?". Itt az ELTE PPK válaszolói adtak kedvezőbb választ. Mindkét intézményi válasz azt mutatja, hogy a kevés az egészségfejlesztés szempontjából mintaadó személy az oktatók és dolgozók és a hallgatótársak között. A PPK-n pedig - a válaszok alapján úgy tűnik, hogy szemben a szombathelyi campusszal - igen alacsony a baleset- és egészségvédelem tájékoztatás hatása.

A munkatársak 53\%-a, a hallgatók 40\%-a szerint nincs az ELTE-n az egészségfejlesztésnek felelőse. Baleset- és egészségvédelmi tájékoztatást a munkatársak 54\%-a, a hallgatók 35\%-a kapott.

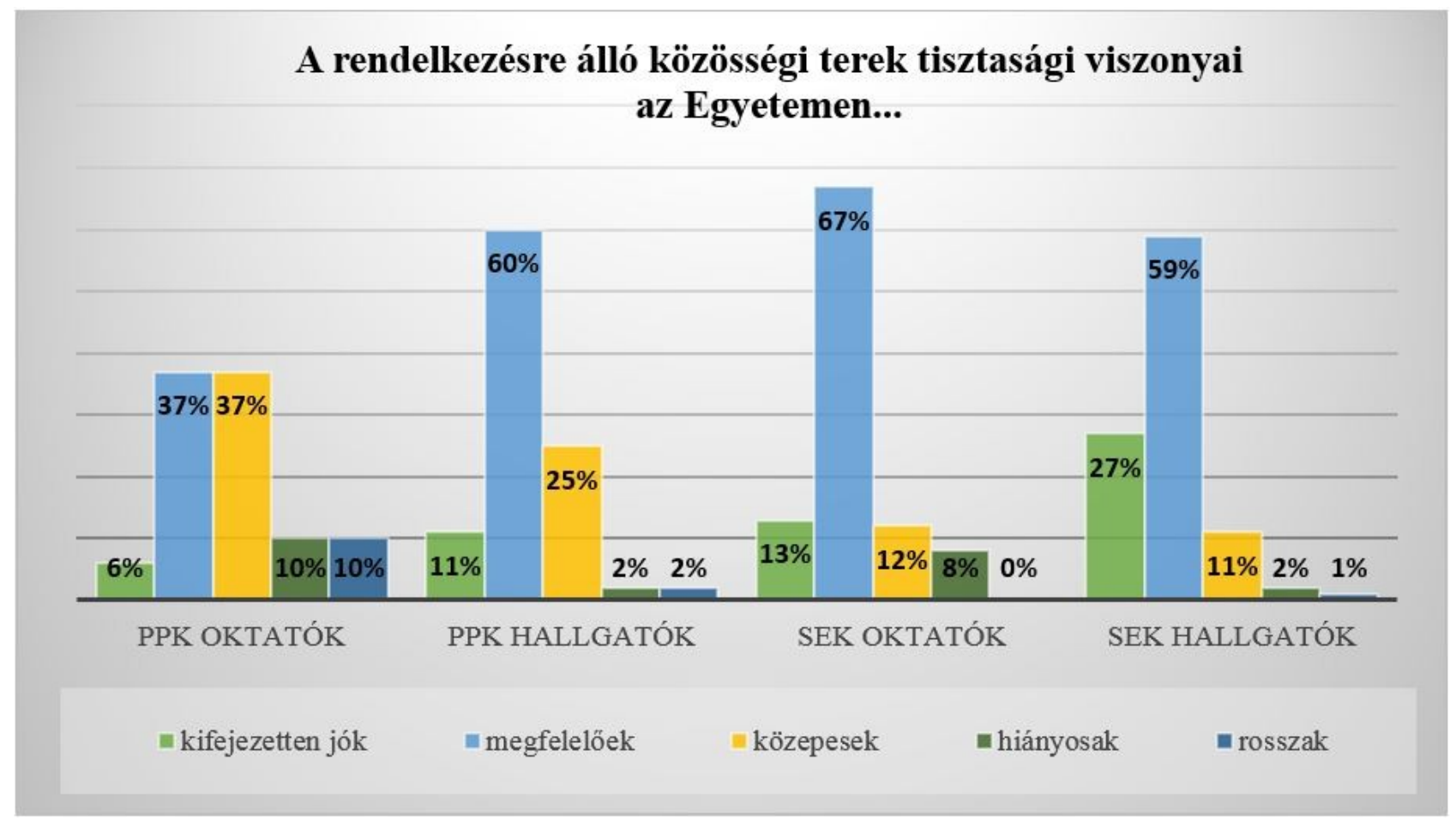

5. ábra: A közösségi terek tisztasága az egyetemen 


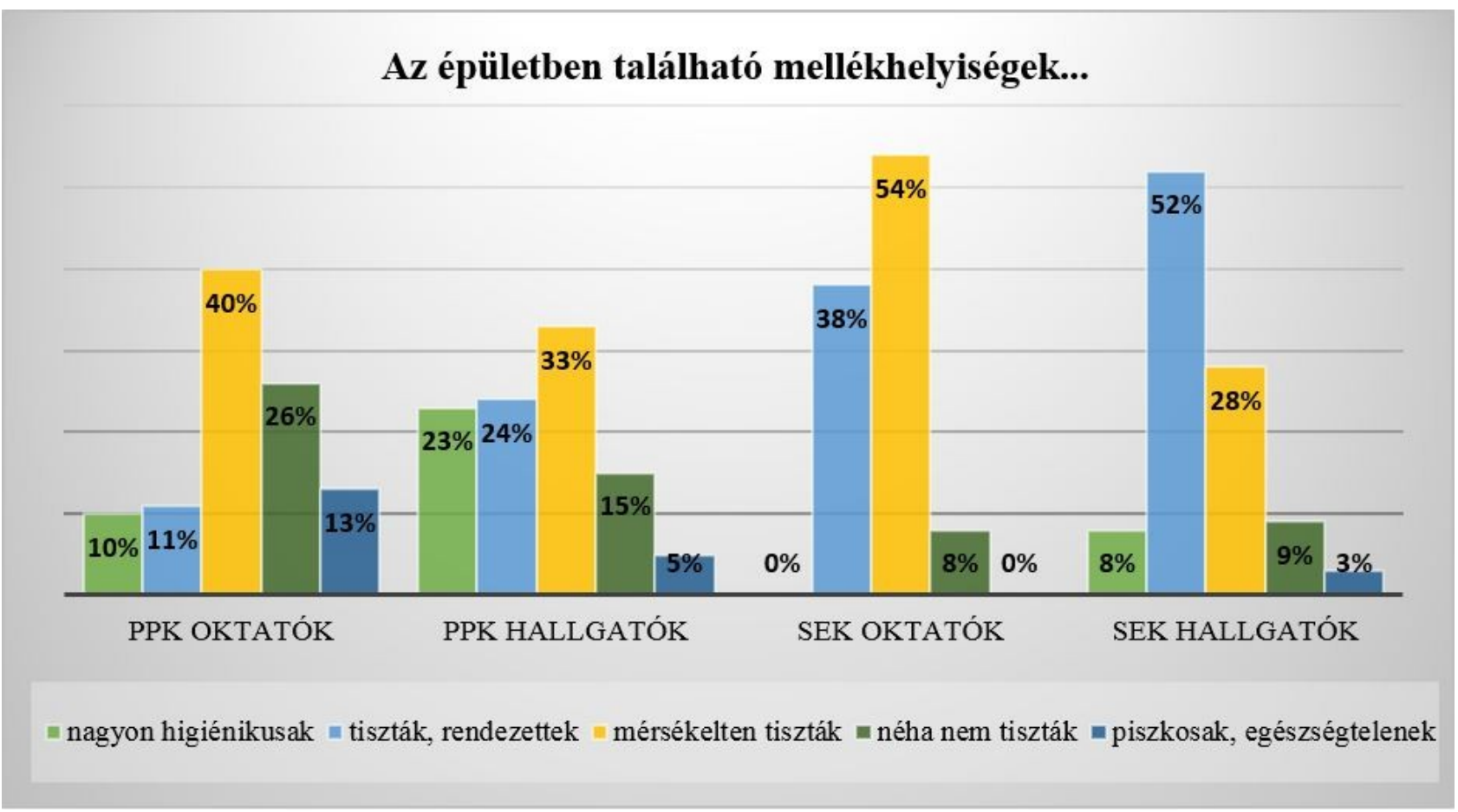

\section{6. ábra: A mellékhelyiségek tisztasága az egyetemen}

Örömteli a közösségi terek higiénés viszonyairól való vélekedés: mindkét karon viszonylag megfelelőnek tartják a közösségi terek tisztasági viszonyait, a mérsékelt tisztaságot választották opcióként. A PPK esetében, mind az oktatók, mind a hallgatók közül többen egészségtelennek és piszkosnak tartják a mellékhelyiségeket (13-5\%).

\section{Orvosi ellátás}

A kutatás során lényegesnek tartottuk rákérdezni az egyetemi egészséggel kapcsolatos szolgáltatások elérhetőségére, és az orvosi ellátottságra, hiszen mind a hallgatók, mind az egyetem dolgozói jelentős időt töltenek az egyetemen és a hallgatók sorában sok a vidéki illetőségú, akik esetleges napi egészségügyi problémáira jog gal az egyetemen keresnek megoldást. Mindkét szervezeti egységben magas azoknak a száma, akiknek nem volt tudomása ilyen szolgáltatásokról. Arra a kérdésre például, hogy van-e tudomásuk szerint orvoshoz fordulási lehetőség az egyetemen, az ELTE oktatók 27\%-a, a hallgatók 82\%-a, a SEK oktatók 33-a, a hallgatók 78\%-a nem tudott választ adni. A hallgatók - különösen a vidéki állandó lakhellyel rendelkezők - mindkét városban sokkal nehezebb helyzetben vannak, mint az oktatók, mert egészségi probléma esetén nem tudják, hogy kihez fordulhatnak. A hallgatók számára jelenleg az ELTE-n belül nincs szervezett orvosi ellátás. A munkavállalók időhiány és egyéb okok miatt nem tudnak olyan gyakorisággal részt venni egészségükkel kapcsolatos szűrővizsgálatokon, ahogy igényük is lenne rá. A Budapesten tanuló, ideiglenes lakóhelyük szerint be nem jelentett hallgatók és oktatók nem jogosultak a fővárosban szűrővizsgálatok igénybevételére.

Az orvosi ellátáshoz kapcsolódik az a kérdés is, hogy a résztvevők tudnak-e valakihez fordulni mentális problémájuk esetén. Ebben a kérdésben nagy a különbség az két intézmény között. Az ELTE PPK-n a helyzet jónak mondható, több mint 30 éve létezik diáktanácsadás és egyéb életvezetési szolgáltatás az egyetem polgá- 
rai számára.: Azonban a SEK-en magas a száma azoknak az oktatóknak és hallgatóknak, akik probléma esetén nem tudnak kihez fordulni az egyetemen. (67-45\%). Mindez az egészségfejlesztéssel kapcsolatos információszolgáltatás hiányosságára hívja fel a figyelmet, amint a 8. és 9. grafikon is mutatja.

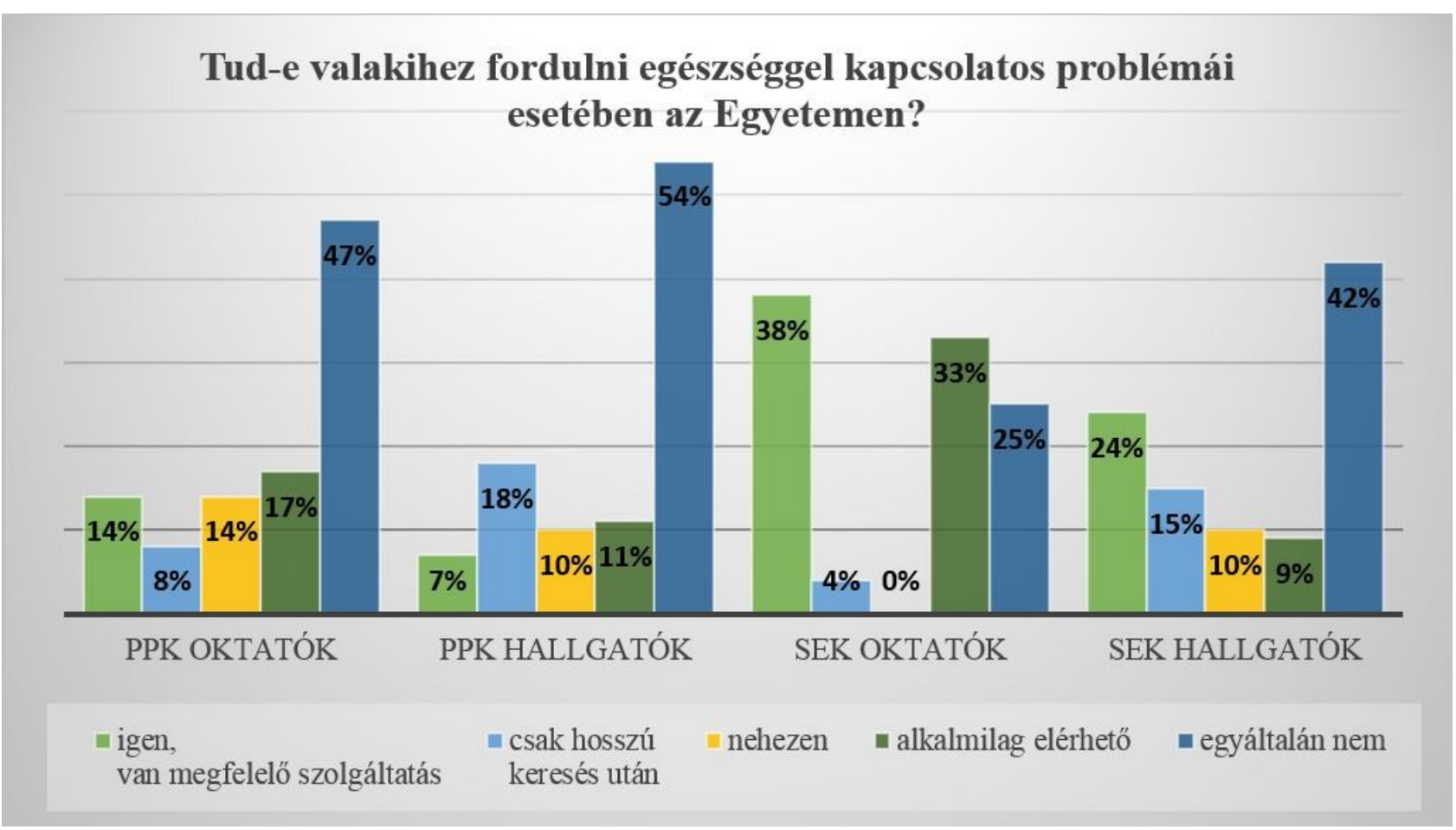

7. ábra: Segítség lehetősége egészséggel kapcsolatos probléma esetén az egyetemen

8. 2016-ban a Magyar Pszichológiai Társaság Tanácsadás Pszichológiai Szekciója és az ELTE Pedagógiai és Pszichológiai Kar Életvezetési Tanácsadó szakemberei közösen szervezték meg az első Pszichológia Tanácsadás Konferenciát, amelyről Karner Orsolya, az ELTE PPK oktatója írt beszámolót. Online megjelenés: https://www.ppk.elte.hu/hir?id=NW-636 (2017. 03. 30). 


\section{Tud-e valakihez fordulni mentális problémái esetében az Egyetemen?}

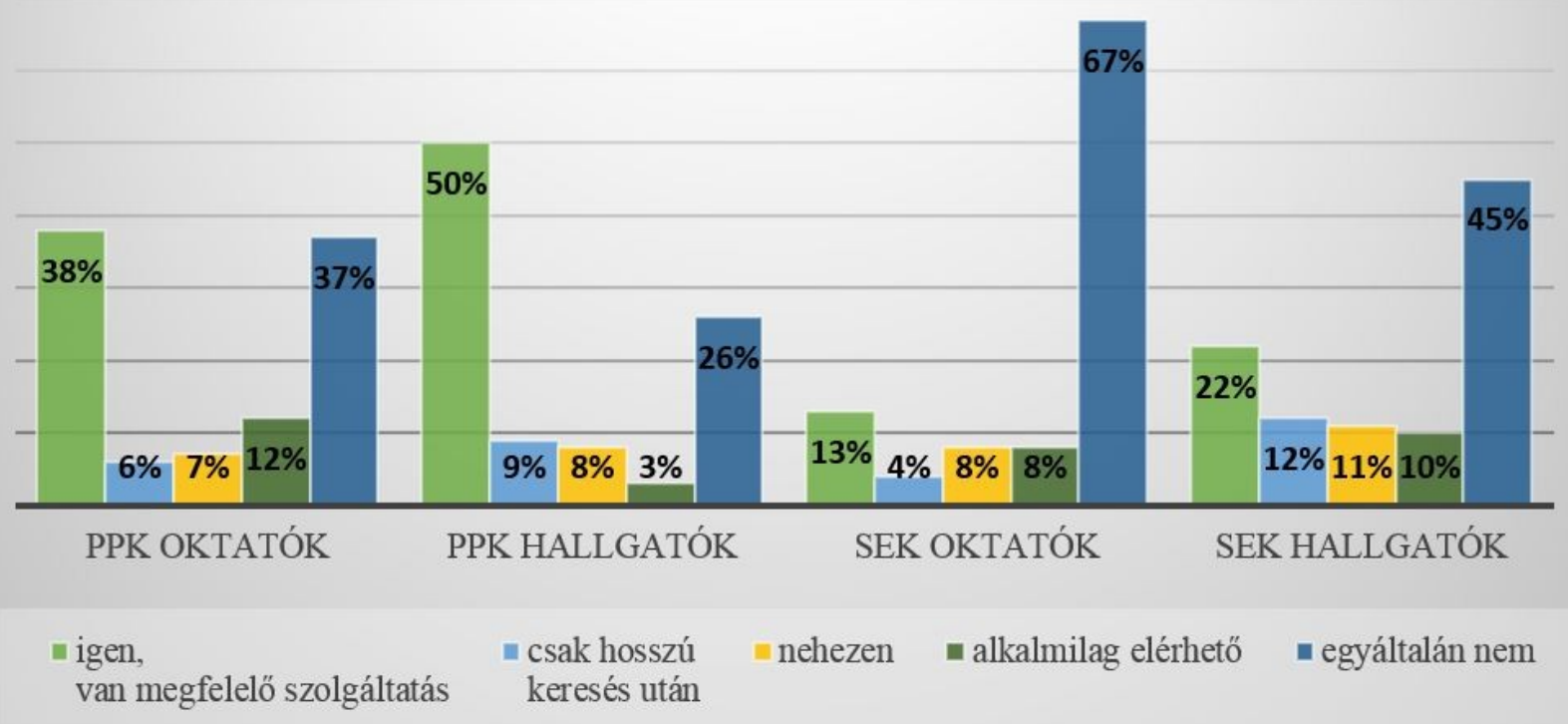

8. ábra: Segítség lehetősége mentális probléma esetén az egyetemen

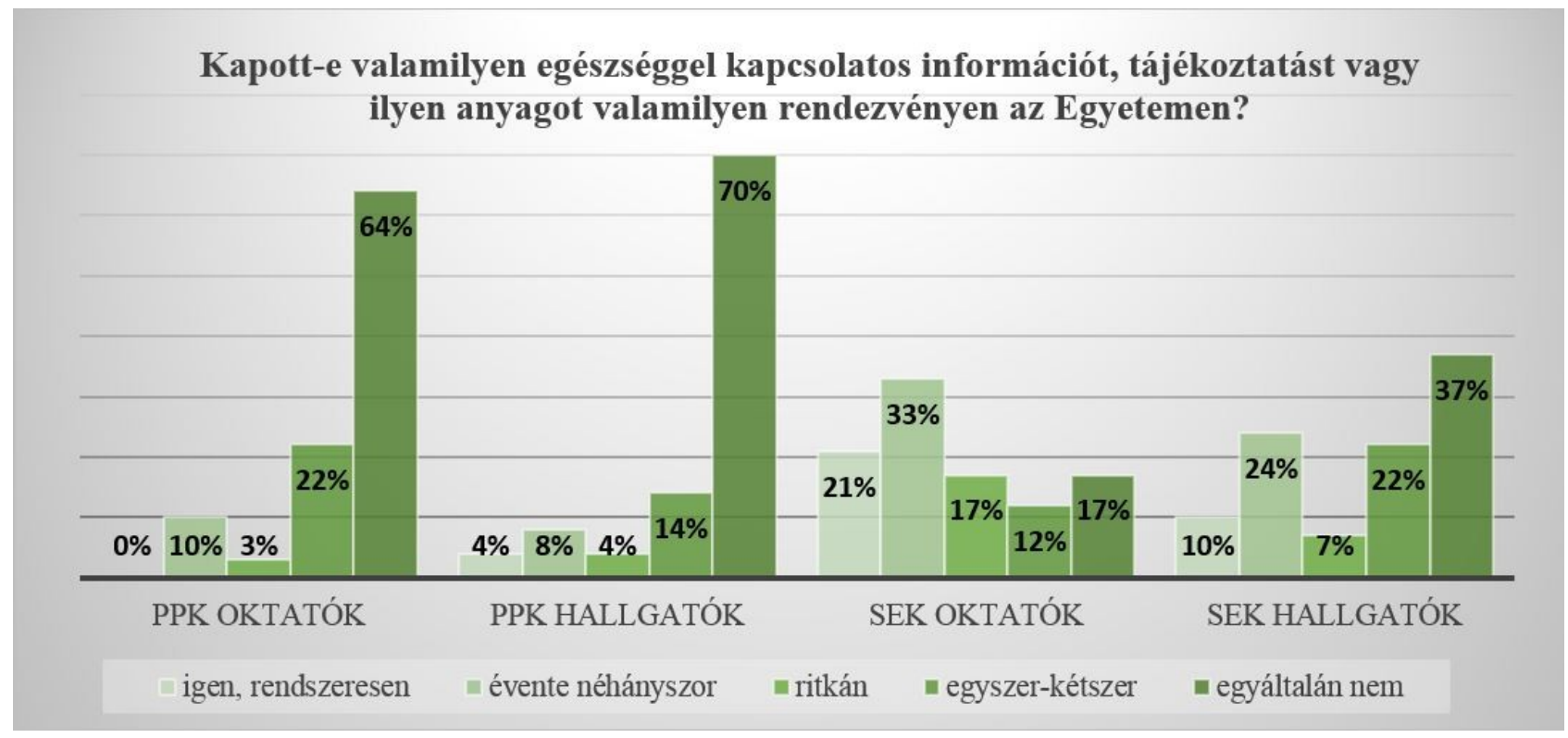

9. ábra: Egészséggel kapcsolatos információk az egyetemen

Végül, de nem utolsó sorban fontos kérdés az egyetemi sportolási lehetőség biztosítása az egyetemi polgárok számára. Ebben a kérdésben a SEK eredményei kedvezőbbek. A PPK oktatói válaszadói közül csupán 20\%, a hallgatók $36 \%$ gondolja, hogy elegendő lehetőség van az egyetemen a szabadidő aktív eltöltésére, sportolás ra. A PPK oktatói közül ráadásul többen úgy vélik, hogy ha van is lehetőség sportolásra, az ELTE földrajzi széttagoltsága miatt a szolgáltató helyek nehezen elérhetők. 


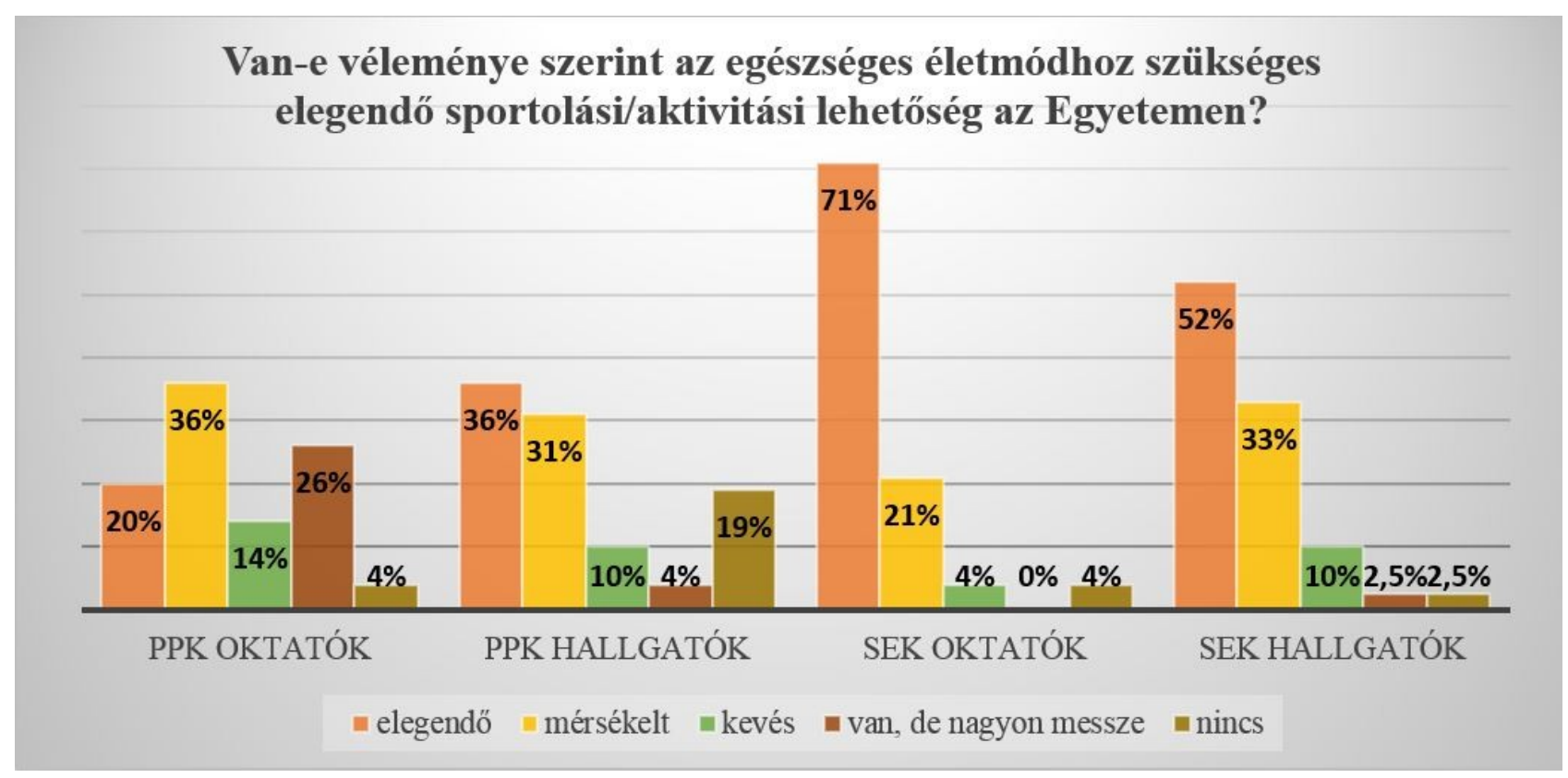

10. ábra Sportolási, fizikai aktivitási lehetőség az egyetemen

\section{A kutatás összefoglalása}

Mind a PPK, mind a SEK válaszadói megerősítették, hogy többségüket érdekli és fontosnak tartják az egyetemi egészségfejlesztést, azonban az intézményi környezet nem igazán járul hozzá az egészséges életmód kialakításához.

A megkérdezettek többsége egészségtudatosnak mondható, figyelmet fordítanak saját egészségükre (SEK oktatók: 63\%; SEK hallgatók: 48\%), s úgy gondolják, hogy hivatásuk példamutató lehet mások számára. A Savaria Egyetemi Központban - mind az oktatók (53\%), mind a hallgatók (58\%) esetében - jelentős azoknak a száma, akik számára létezik az egészségfejlesztés szempontjából mintaadó személy az egyetemen.

Az ELTE PPK megkérdezett oktatóinak 49\%-a, SEK oktatóinak 58\%-a tartja kiemelten fontosnak az egészségfejlesztést az egyetemen. A hallgatók esetében az arány fordított: az ELTE PPK megkérdezett hallgatóinak 42\%-a, a SEK hallgatóinak 33\%-uk tartja kiemelten fontosnak az egészségfejlesztést az egyetemen.

Intézményi szinten az egészségfejlesztést leginkább akadályozó tényezők közül kiemelkedik az étkezési körülmények kedvezőtlen volta: az étkeztetési szolgáltatásokról való tájékoztatás hiánya, a nyitvatartás kedvezőtlen rendje, a büfék korszerútlen, az egészséges táplálkozást kevéssé figyelembe vevő kínálata. A legnagyobb probléma mégis az, hogy általában az órarendek kialakítása nem teszi lehetővé a rendszeres étkezést.

Bár a vizsgálatban nem merült fel a mozgás, a sport-rekreációs lehetőségek hiánya, mégis szembetűnő, hogy sokan nem élnek a rendelkezésre álló sport-rekreációs lehetőségekkel. A PPK estében ennek egyik oka az egyetemi létesítmények széttagoltsága, a sportlétesítmények távolsága.

Az egészség általános mutatói (például BMI érték) az ELTE PPK válaszadói esetében kicsit kedvezőbbek, a Savaria Egyetemi Központban viszont több a sportolási lehetőség és nagyobb arányú azok igénybevétele, valamint magasabb az egészséggel kapcsolatos rendezvények száma. Összességében azonban megállapítható, hogy mindkét szervezet mintájában kedvezőtlenül magas a dohányzás és az alkoholfogyasztás mutatója. 


\section{Irodalom}

1. Bárdos, Gy. Életmód és egészség - avagy mit tehetünk a saját egészségünkért. In Kraiciné Szokoly, M., Pápai, A., \& Perjés, I. (2013, Ed.). Európai Léptékkel - Az élethosszig tartó tanulás társadalmi folyamatai és biopszichoszociális háttere. (pp. 144-150). Budapest: ELTE Eötvös Kiadó.

2. Bárdos, Gy. \& Kraiciné Szokoly M. (2018). Egészség, életmód, egészségfejlesztés a felsőoktatás szemszögéből. Neveléstudomány 7, 2. 5-21.

3. Benkő, Zs. (1997, Ed.): Az egészségfelfogás változása. Kísérlet az egészségfejlesztés értelmezésére. In Benkő Zs (1997; 2003, Ed.): „Mert életem millió gyökerü” (pp. 5-15). Egészségfejlesztés Mentálhigiéné sorozat. Szeged: JGYTF.

4. Benkő, Zs. (2009). Egészségfejlesztés. Szeged: Mozaik Kiadó.

5. Bíróné Nagy, E. (2011, Ed.). Sportpedagógia - Kézikönyv a testnevelés és sport pedagógiai kérdéseinek tanulmányozásához. Budapest: Dialóg Campus Kiadó-Nordex Kft.

6. Borbás, I., Gődény, S., Juhász, J., Kincses, Gy., Mihalicza, P., Pékli, M. \& Varga, E. (2008, Ed.). Egészségtudományi fogalomtár. Gyógyszerészeti és Egészségügyi Minőség- és Szervezetfejlesztési Intézet Informatikai és Rendszerelemzési Főigazgatóság. Retrieved from: http://fogalomtar.eski.hu/index.php/ (2015. 03. 24.).

7. Buda, B. (1994). Mentálhigiéné - A lelki egészség társadalmi, munkaszervezeti, pszichokulturális és gyakorlati vetületei, Tanulmánygyüjtemény. Budapest: Animula Egyesület.

8. Cueto, M. (2004). The Origins of Primary Health Care and Selective Primary Health Care. Am J Public Health. 94. 11. 1864-1874. Retrieved from: http://www.ncbi.nlm.nih.gov/pmc/articles/PMC1448553/ (2017. 04. 13.)

9. Czippán, K., Drahos, P., Gilly, Gy., Koós, T., \& Székely, M. (2015, Ed.). Egészségfejlesztő Egyetem Program: Alapelvek, célok, koncepciók, az egészségfejlesztés felsőoktatási környezetben való értelmezése a megvalósítás elvi és gyakorlati szempontjai és teendői. TÁMOP 6.1.1. 1/12/1 Fejlesztői kézikönyv. Budapest: OEFI.

10. Engel, G. L. (1997). The Need for a New Medical Model: A Challenge for Biomedicine. Science, Volume 196, 4286. 129-136.

11. Érdekességek a szubjektív jóllét (well-being) magyarországi vizsgálatából. (2014., Ed.). KSH Statisztikai Tükör. 8, 2. 1-4.

12. Gritz, Ané (2007). Az egészségfejlesztés kompetenciái a XXI. században. Egészségfejlesztés, 48, 3. 3-9.

13. Hamvai, Cs. \& Pikó, B. (2009). Serdülők szubjektív jóllétét meghatározó társas tényezők a családban és az iskolában. Új Pedagógiai Szemle. 4, 30-43.

14. Harsányiné Petneházi, Á. (2013). Társas háló és pszichés és jóllét összefüggései a Hátrányos Helyzetú Tanulók Arany János Tehetséggondozó Programjában. Iskolakultúra, 13, (5-6). 53-64.

15. Kishegyi, J. \& Makara, P. (2004, Ed.). Az egészségfejlesztés alapelvei. Az egészségfejlesztés alapvető nemzetközi dokumentumai. Budapest: OEFI Retrieved from: http://www.oefi.hu/modszertan1.pdf (2015. 02. 22.).

16. Kishegyi, J. \& Makara, P. (2004, Ed.). Egészségfejlesztés és közösségfejlesztés a színtereken. Budapest: OEFI.

17. Kishegyi, J. \& Makara, P. (2004, Ed.). Kutatás-monitorozás, értékelés az egészségfejlesztésben. Budapest: OEFI.

18. Koós, T. (2014, Ed.). Az egészség-egyenlötlenségek csökkentése dokumentumgyüjtemény. Budapest: OEFI.

19. Kozmann, Gy., Nagy, A., Pásztélyi, Zs. \& Tamás, É. (2006). Bangkoki charta az egészségfejlesztésért a globalizált világban. IME Online, 5, 3.18-20. Retrieved from: http://www.imeonline.hu/article.php? article=2006._V./3/bangkoki_charta_az_egeszsegfejlesztesert_a_globalizalt_vilagban (2016.11. 11.) 
20. Kraiciné Szokoly, M. (2016). Egészségfejlesztés a felsőoktatásban - Gondolatok egy felsőoktatást érintő projekt zárása kapcsán. Opus et Educatio, 3, 5. 511-528. Retrieved from: http://opuseteducatio.hu/index.php/opusHU/article/view/142/179 (2017. 04. 14.).

21. Makra, G. \& Balogh, L. (2018). Examination of the Relationship Between Physical Activity and Cognitive Skills. STADIUM - Hungarian Journal of Sport Sciences, 1(1), 1-15.

22. Nagy, Zs. (2011, Ed.). A WHO Egészséges Városok programja Magyarországon. Pécs: Az Egészséges Városok Magyar Nyelvű Szövetségének Kiadványa.

23. Ottawai Karta, Ottawa Charter for Health Promotion. (1986). Retrieved from: http://www.who.int/ healthpromotion/conferences/previous/ottawa/en/ (2017. 07. 30)

24. Petőné Csima, M. (2012). Az egészségmagatartás és a koherencia-érzet szerepe az életminőség formálásában. Doktori $(\mathrm{PhD})$ értekezés. Pécs. Retrieved from:

http://www.nevtudphd.pte.hu/files/tiny_mce/Vedesek/2012/petone_csima_melinda__disszertacio.pdf (2015. 02. 22.).

25. St Leger, L. (2001). Schools, health literacy and public health: possibilities and challenges. Health Promotion International, 16(2) 197-205, Retrieved from https://academic.oup.com/heapro/article/16/2/197/653451 (2019. 01. 14.)

26. Székely, L., Simon, T. \& Vergeer, F. (2007). Az „egészség” fogalmának újraértelmezése I. Egészségfejlesztés, 48, 4-6. 37-47.

27. WHO (1948). Preamble to the Constitution of WHO as adopted by the International Health Conference, New York, 19 June - 22 July 1946; signed on 22 July 1946 by the representatives of 61 States (Official Records of WHO, 2, p. 100) and entered into force on 7 April 1948.

28. WHO (1978). Declaration of Alma-Ata Retrieved from: http://www.who.int/publications/almaata_declaration_en.pdf (2017. 03. 17.)

29. WHO (1984). A Discussion Document on the Concept and Principles of Health Promotion, Copenhagen, 9-13 July 1984. Retrieved from http://apps.who.int/iris/bitstream/10665/107835/1/E90607.pdf (2017. 01. 12.)

30. WHO (1986). The Ottawa Charter for Health Promotion Retrieved from http://www.who.int/healthpromotion/conferences/previous/ottawa/en/ (2017. 04. 04.)

31. WHO (2006). The Bangkok Charter for Health Promotion in a Globalized World. Health Promotion International, 21. 1. 10-14. Retrieved from http://www.who.int/healthpromotion/conferences/6gchp/ bangkok_charter/en/ (2017. 01.05.)

32. WHO (2009). 7th Global Conference on Health Promotion Retrieved from http://www.who.int/healthpromotion/conferences/7gchp/en/ (2017. 01. 07.) 


\section{Health Promotion Situation at The Eötvös Loránd University Faculty Of Education and Psychology}

The Senate of ELTE has passed the Health Promotion Strategy of the University in autumn of 2018. This document emphasizes the significant societal role of the professionals regarding public health, as well as the role of the University in establishing health related approaches and health conscious life-style of the students. Before completing the strategy, a questionnaire study had been completed in the 2015/16 and 2016/17 terms, respectively, at the Faculty of Education and Psychology of ELTE about the situation of health promotion. Main topics were how the students and teachers, respectively, think about their health state, about the health-related environment at the university and about whether they are conscious about their professional and societal responsibility. This study has been repeated due to the fact that, associated with the reformulation of the higher education, some units of the Faculty of Education of the Berzsenyi Dániel West-Hungarian University joined to the Faculty of Education of ELTE in 2017, thus a comparison of samples from the Capital and from Transdanubium had become possible.

According to the results of the questionnaire study, half of the interviewed teachers and somewhat less than half of the students think that health promotion at the University is important but does not have primary relevance. They stress the significance of nutrition and physical activity but think the university environment does not favour these. Obstructive factors are the unfavourable prandial circumstances and that, due to the spatial diversity, timetables do not provide enough time for regular dining of the students and teachers. According to the results of both the capital and rural studies, health related general indicators are unfavourable, and incidence of smoking and alcohol consumption is high. In both groups, participants spend average time sleeping, whereas the time spent on the Internet is high. Participants are unsure about the effectivity of their own health behaviour, and cannot see health-associated aspects of their profession, either.

Keywords: health promotion, student-teacher lifestyle, health promoting university environment 